\title{
TAFSIR FEMINIS: SEJARAH, PARADIGMA DAN STANDAR VALIDITAS TAFSIR FEMINIS
}

\author{
Eni Zulaiha \\ Dosen Fakultas Ushuluddin UIN Sunan Gunung Djati Bandung \\ Jl. A.H. Nasution 105 Cibiru Bandung 40614, Indonesia. \\ E-mail: enzul72@gmail.com
}

\begin{abstract}
Feminist exegesis (tafsir) is a unique genre emerges in contemporary era when gender issue become a global concern. The paradigm of this tafsir started from the asumpsion that the Alquranic principle of male-female relationship should be based on justice (al-'adālah), equality (al-musāwah), appropriateness (al-ma'rüf), and conssensus (syüra). Thus, any exegesis produced in classical period which violate all those principles are considered unacceptable, especially in relation to the current situation which differ from that of previous time. Feminist tafsir employs gender analisys as a tool to differentiate between God given condition that is unchangeable to gender as social construction that is changeable. In addition, hermeneutics is considered an appropriate approach chosen in feminist tafsir along with thematic method to interprete verses about gender relation in the Alquran. With this methodology, its aim is to produce tafsir with more intersubjective and critical insight related to gender relation.
\end{abstract}

Keywords:

Feminist exegesis; history; feminist tafsir validity.

\begin{abstract}
Abstrak
Tafsir feminis merupakan sebuah genre tersendiri yang muncul di era kontemporer ketika isu gender menjadi isu global. Paradigma tafsir ini berawal dari asumsi, bahwa prinsip dasar Alquran dalam relasi laki-laki dan perempuan adalah keadilan (al-'adālah), kesetaraan (al-musāwah), kepantasan (al-márüf), musyawarah (syüra). Apabila terdapat produk-produk penafsiran klasik yang bertentangan dengan prinsip-prinsip tersebut akan dinilai tidak tepat, terutama ketika diterapkan dalam konteks kekininian, disebabkan situasi dan kondisinya jelas berbeda antara zaman dulu dan sekarang. Model analisis yang dipakai dalam paradigma tafsir feminis adalah analisis gender,yang secara tegas membedakan antara kodrat sebagai sesuatu yang tidak bisa berubah, dengan gender sebagai konstruksi sosial yang bisa berubah. Wajar jika kemudian pendekatan hermeneutik dengan metode tafsir tematik akhirya menjadi pilihan dalam mengkaji ayat-ayat tentang relasi gender. Sebab dengan metodologi seperti itu, diharapkan produk tafsir akan lebih intersubyektif dan kritis melihat problem relasi gender.
\end{abstract}

\section{Kata Kunci:}

Tafsir feminis; sejarah; validitas tafsir feminis.

\section{A. PENDAHULUAN}

Fenomena perdagangan perempuan dan anak, kekerasan dan pelecehan seksual terhadap mereka seakan tak pernah terlewatkan dalam berita-berita kriminal, baik melalui media massa maupun media elektronik dan juga media online. Ironisnya, fenomena itu juga terjadi di negara-negara yang mengaku sebagai negara Islam, seperti Malaysia dan Saudi Arabia. Tidak sedikit korban kekerasan yang dilakukan oleh sebagian majikan terhadap para TKW Indonesia yang bekerja di sana.

Diakui atau tidak, dehumanisasi (al-lā insāniyyah) terhadap kaum perempuan pernah terjadi dalam panggung sejarah.Bahkan hingga sekarang, kondisi tersebut masih dapat kita saksikan. Betapa di Indonesia yang mayoritas penduduknya muslim, kaum perempuan masih dianggap sebagai kelas dua (second class) oleh sebagian masyarakat yang belum memiliki sensitifitas gender. Sehingga apresiasi terhadap kaum perempuan belum sepenuhnya tercermin dalam pola perilaku masyarakat kita.Di beberapa daerah,kelahiran anak perempuan kadang masih dinggap kurang membanggakan dibanding anak lakilaki. Perlakuan dan pola asuh terhadap anak perempuan sering masih dibedakan dengan anak laki-laki. Semua itu jika dibiarkan tentu 
akan berdampak pada ketidakadilan dan diskriminasi gender. Padahal Alquran sebagai kitab suci secara normatif sangat menghargai perempuan.

Ada banyak faktor penyebab mengapa kaum perempuan mengalami bias (ketimpangan) gender, sehingga mereka belum setara. Pertama, telah membudaya sedemikian lama dimasyarakat budaya patriarki. Kedua, faktor politik, yang belum sepenuhnya berpihak kepada kaum perempuan.Ketiga, faktor ekonomi dimana sistem kapitalisme global yang melanda dunia, seringkali justru mengeksploitasi kaum pe-rempuan.Keempat, faktor interpretasi teks-teks agama yang bias gender. Kelima, menurut Nurofia'ah,bahasa Arab yang menjadi bahasa umat Islam mengandung bias gender yang mempengaruhi proses tekstualisasi firman Allah dalam bentuk Alquran. ${ }^{1}$ Hal tersebut dapat ditinjau dari tatabahasa Arab yang merefleksikan budaya dan sikap masyarakat Arab terhadap perempuan. Terlihat pada masa turunnya Alquran, kehadiran anak perempuan dapat mengancam kehormatan sebuah keluarga Arab sehingga penguburan bayi perempuan hidup-hidup juga ditempuh untuk menutupi malu. ${ }^{2}$ Penguburan ini ditempuh karena masyarakat belum mengenal aborsi. Nilai perempuan tak lebih dari barang yang dapat dijual dan diwariskan. ${ }^{3}$ Di samping itu, laki-laki dapat mengawini perempuan dalam jumlah tak terbatas pada saat yang sama, menceraikan mereka, merujuk lagi kapan saja dan berapa kalipun laki-laki

\footnotetext{
${ }^{1}$ Nasr Hamid Abu Zaid, Women in the Discourse of Crisis, The Legal Research and Resource Center for Human Right pages. (LRRC). Cairo, Egypt.

${ }^{2}$ Realitas ini terekam dalam ayat al-Alquran sebagai berikut:

Ketika dikabarkan kepada seseorang di antara mereka perihal kelahiran anak perempuan, wahjahnya cemberut menahan sedih. Ia bersembunyi dari orang banyak disebabkan buruknya berita yang diterimanya, boleh jadi ia akan memeliharanya dengan penuh hina atau menguburkannya (hidup-hidup) ke dalam tanah. Alangkah buruknya keputusan mereka (al-Nahl, [16]:58-59).

${ }^{3}$ Al-Thabāri, Jamī' al-Bayān, vol. VII (Kairo: 105719690, jilid VII), 599.
}

menghendaki. ${ }^{4}$ Tidak jarang perempuan dipandang seperti syaitan yang harus dijauhi. ${ }^{5}$ Kondisi atau konteks yang berubah inilah yang hendak disikapi oleh para mufassir feminis untuk mencoba merespon ayat-ayat yang secara tekstual-literal mengandung biasbias patriarki. Jadi, sama sekali tidak bermaksud merubah Alquran, tetapi memberi alternatif baru dalam memahami Alquran, yakni dengan menangkap gagasan utamanya (maghza) di balik makna literal.

Produk penafsiran tidak dapat dipungkiri merupakan imbas dari model paradigma yang dipakai oleh para mufassir. Untuk melahirkan suatu produk tafsir yang lebih mencerminkan nuansa kesetaraan diperlukan paradigma baru dalam memaknai Alquran. Itulah sebenarnya kegelisahan para mufassir feminis muslim,agar bisa melahirkan tafsir baru yang dapat menjawab tantangan perubahan zaman, tetapi tetap diilhami oleh nilai-nilai moral Alquran yang fundamental.

Kegelisahan para mufassir feminis antara lain disebabkan ketika mereka membaca produk penafsiran ulama klasik, ternyata kurang mencerminkan keadilan gender. Padahal pandangan dunia (world view) Alquran jelas-jelas ingin mendudukkan lakilaki dan perempuan secara setara (equal).

Tulisan ini akan membahas hal-hal yang berkaiatan dengan bagaimana faktor- faktor kemunculan dan sejarah kelahiran tafsir feminis. Selain itu dilengkapi juga dengan pembahasan paradigma dan strandar validitas tafsir feminis.

\section{B. HASIL DAN PEMBAHASAN}

\section{Tafsir Feminisme: Gerakan dan Wacana}

Kata feminis ditinjau secara etimologis ialah "feminisme" yang berasal dari bahasa latin, yaitu "femina" atau dalam bahasa Inggris diterjemahkan menjadi feminine, artinya memiiki sifat-sifat

\footnotetext{
${ }^{4}$ Al-Thabāri, Jamī' al-Bayān, 534-535.

${ }^{5}$ Perempuan adalah setan yang telah diciptakan untuk laki-laki, kami berlindung kepada Allah dari seburukburuk setan yang menggoda. Lih. Muhammad bin Iyās,

Badāiz Zuhūr fì Waqāid Duhūr, (Beirut: Maktabah, tt.), 52 .
} 
keperempuanan. Kemudian kata itu ditambah "ism" menjadi feminism, berarti paham keperempuanan yang ingin mengusung isu-isu gender berkaitan dengan nasib perempuan yang belum mendapatkan perlakuan secara adil di berbagai sektor kehidupan, baik sektor domestik, politik, sosial, pendidikan maupun ekonomi. Perkembangan selanjutnya, kata tersebut ditujukan sebagai teori persamaan kelamin (sexual equality) dan secara historis, istilah tersebut muncul pertama kali pada tahun 1895, dan sejak itu pula feminisme dikenal secara luas.

Feminisme merupakan konsep yang timbul erat kaitannya dengan perubahan sosial (social change), teori-teori pembangunan, gerakan pembebasan kaum perempuan, kesadaran politik perempuan dan termasuk pemikiran kembali terhadap institusi keluarga dalam konteks masyarakat dewasa ini. Memang tidak mudah untuk merumuskan definisi feminisme yang dapat diterima dan diterapkan pada semua feminis dalam semua waktu dan tempat. Sebab feminisme tidak mengambil dasar konseptual dan paradigmanya dari rumusan teori yang monolitik.Oleh karenanya, pengertian feminisme menjadi multifaces (banyak wajah) dan beragam. definisi tentang feminisme bukan merupakan state of being, melainkan state of becoming yang akan selalu dinamis. Dengan kata lain, pengertian feminisme akan selalu mengalami perubahan sesuai dengan perbedaan realitas sosiokultural, bahkan politik yang melatarbelakangi lahirnya gerakan tersebut. Di samping itu, feminisme akan mengalami perkembangan disebabkan oleh perbedaan tingkat kesadaran, persepsi serta tindakan yang dilakukan oleh para feminis sendiri.

\footnotetext{
${ }^{6}$ Lisa Turtle, Encyclopedia of Feminisme (New York: Facts of File Publication, 1986), 107. Lihat pula, John M. Echol dan Hassan Shadily, Kamus InggrisIndonesia, Cet. XIX (Jakarta: Gramedia, 1993), 237.

${ }^{7}$ Lis Markus, "Feminisme dalam Wacana dan Gerakan Perempuan Era Postmodernisme", Makalah, disampaikan dalam halaqoh ulama perempuan LSM
}

Sekurang-kurangnya, istilah feminisme dapat mencakup tiga poin penting: (1) feminisme sebagai pengalaman hidup. (2) feminisme merupakan alat perjuangan politik bagi pembebasan manusia, khususnya perempuan.Gerakan ini disebut sebagai liberation movement, gerakan pembebasan yang intinya menuntut persamaan dalam struktur sosial politik. (3) feminisme merupakan aktivitas intelektual. Maksudnya gerakan feminisme ini memberikan pemahaman terhadap kehidupan sosial, di mana perempuan itu tinggal, kekuatan apa yang dapat dilakukan untuk melakukan perubahan ke arah perbaikan nasib perempuan dan mampu mengetahui apa yang harus diperjuangkan, bagaimana mendefinisikan bentuk-bentuk penindasan atas perempuan dan lain sebagainya.

Feminisme sebagai suatu gerakan muncul di Amerika sekitar akhir abad 19 atau awal abad 20. Gerakan ini dulunya difokuskan untuk mendapatkan hak memilih (the right to vote).Namun demikian, setelah hak-hak itu diperoleh pada tahun 1920, gerakan ini sempat tenggelam lagi. Baru kurang lebih tahun 1960an terutama setelah Betty Friedan menerbitkan bukunya The Feminine Mystique (1963), gerakan ini sempat mengejutkan bagi masyarakat, karena mendorong kesadaran baru, terutama bagi kaum perempuan, bahwa peran-peran tradisional selama ini ternyata menempatkan mereka dalam posisi yang tidak menguntungkan, yaitu subordinasi dan marginalisasi kaum perempuan.

Sampai akhir tahun 1980-an, teori feminisme menunjukkan pola berulang. Analisisnya merefleksikan pandanganpandangan perempuan kelas

\footnotetext{
${ }^{8}$ Kamla Bashin dan Nighat Said Khan, Persoalan Pokok Mengenai Feminisme dan Relevansinya, Terj, S. Harlina (Jakarta: Gramedia, 1995), 4.

${ }^{9}$ Bandingkan dengan Robeka Harsono, "Merancang Gerakan Generasi Muda... hlm. 12.

${ }^{10}$ Ratna Megawangi, "Feminisme: Menindas Peran Ibu Rumah Tangga", dalam Ulumul Qur'an, edisi khusus No: 5 \& 6 Vol V, (1994), 30-41. Lihat pula, Anang Haris Himawan, "Teologi Feminisme dalam Budaya Global: Telaah Ktitis Fiqh Perempuan", dalam Jurnal Ulumul Qur'an, No: 4 Vol VII, (1997), 35-42.
} 
menengah Amerika Utara dan Eropa Barat.Namun sayangnya secara akademis ada kecenderungan di Barat untuk semakin maskulinis. Sebab secara tidak disadari, feminis akademis di Barat telah terkooptasi oleh hirarki, mekanisme kerja, cara berpikir, epistimologi dan metodologi maskulin. ${ }^{11} \mathrm{Hal}$ ini jelas akan dapat "membahayakan" feminisme itu sendiri. Sebab suatu gerakan yang tadinya dimaksudkan untuk pembebasan (liberation: taharrur) malah berbalik menjadi opressive (menindas). Dengan demikian, maka menjadi kurang tepat dan akan mengalami banyak kendala, jika feminisme di Barat yang cenderung chauvinistic (bersifat patriotik yang berlebihan) diterapkan secara mentah-mentah dalam konteks Asia dan Indonesia khususnya. Sebab di samping kultur budaya yang berbeda, sangat mungkin ide pembebasan perempuan yang dicita-citakan akan berubah menjadi perlawanan atau bahkan penindasan terhadap laki-laki. Oleh karena itu, menurut hemat penulis, yang diperlukan dalam rangka membebaskan dan membentuk sistem struktur masyarakat yang adil adalah bukan gerakan anti-feminisme yang tradisional-konservatif atau pro-feminisme yang modern progressivechauvinistik, melainkan suatu gerakan pasca feminisme Islami-integratif yang meletakkan perempuan sebagai mitra bagi lelaki.Bukan feminisme sebagaimana dipersepsi sebagian kaum feminis modern yang meletakkan perempuan sebagai rival.Bukan pula subordinasi perempuan di bawah lelaki seperti yang dipersepsikan oleh para anti-feminisme tradisional.

Di Indonesia kajian feminisme baru muncul secara transparan kurang lebih tahun 1980-an. Hal tersebut terlihat dari munculnya para aktifis gerakan perempuan, seperti Ratna Megawangi, Herawati, Wardah Hafidz, Yulia Surya Kusuma, Marwah Daud Ibrahim dan lain sebagainya. Menurut hemat penulis, gerakan feminisme ini muncul karena adanya kesadaran bahwa dalam sejarah peradaban manusia termasuk di

\footnotetext{
${ }^{11}$ Suryakusuma,"Specific Methodological Problem in Feminism Research", dalam State Ibuism: The Social Construction of Womenhood in Indonesia New Order,(Tesis di Den Haag, 1987), 162-175.
}

Indonesia, perempuan telah diperlakukan secara kurang adil, bahkan dilecehkan sama sekali. Namun anehnya, hal ini dilakukan secara sistematis karena adanya dominasi budaya patriarki yang kuat dalam kesejarahan manusia. Maka, kritik yang tajam selalu diarahkan pada persoalan sistem patriarki, genderisme dan seksisme. ${ }^{12}$.

Berbeda dengan feminis di negara lain, feminis indonesia memiliki kekhasan sendiri dalam gerakan dan wacananya. Misalnya jika kita lihat beberapa tulisan Husein Muhammad dan Musdah Mulia, beberapa isu yang diangkat tidak sama dengan tema-tema yang dibahas feminis luar Indonesia. Feminis Indonesia lebih banyak menyintesakan apa yang sudah dibahas oleh feminisme sebelumnya dan merumuskan sesuatu yang baru.

\section{Sebab-Sebab Lahirnya Tafsir Feminis}

Penafsiran umat Islam terhadap ayat-ayat yang berkaitan dengan relasi laki-lakiperempuan pada dasarnya bisa dipilah menjadi dua macam. Pertama, penafsiran yang dilandasi dengan kerangka pendekatan patriarkal.Dan kedua, penafsiran yang dilandasi dengan pendekatan feminis.

Sebagai perbandingan, antara penafsiran yang dilandasi dengan pendekatan patriarkis, dan tafsir feminis. Penafsiran yang patriarkal, biasanya dilakukan secara eksklusif oleh mayoritas kaum laki-laki (mayoritas), yang kemudian mengakibatkan dalam tafsirnya tidak mewakili kepentingan dan pengalamanperempuan karena penulisnya hanya laki-laki dan pengalaman laki-laki saja yang dimasukkan ke dalam penafsiran tersebut. Sementara perempuan dan pengalaman kehidupannya ditiadakan. Karena dari perspektif, visi, kebutuhan atau keinginan kaum perempuan ditafsirkan menurut paradigma kaum laki-laki. Pembuatan paradigma dasar yang digunakan untuk menelaah dan menafsirkan Alquran dilakukan tanpa melibatkan pandangan kaum perempuan sebagai pihak pertama.

\footnotetext{
${ }^{12}$ Bandingkan dengan tulisan M. Arif Hakim, "Gerakan Perempuan dalam Perspektif Ideologis", dalam Media Indonesia, 14 Agustus, 1993.
}

Bayan: Jurnal Studi Al-Qur'an dan Tafsir 1,1 (Juni 2016): 17-26 
Sementara itu dalam penafsiran yang dilakukan dengan menggunakan pendekatan feminis, yang ditujukan sebagai reaksi atas penafsiran yang patriarkal, didasarkan atas kenyataan bahwa secara sosial, perempuan cenderung dinomorduakan dalam berbagai aspek.Bahwa dalam kehidupan sosial kaum perempuan sering mengalami ketertindasan, tidak bisa dilepaskan dari penafsiran agama yang patriarkal tersebut. Oleh sebab itu, dalam pendekatan feminis terhadap teks-teks keagamaan ini, kerangka yang dikedepankan adalah soal kesetaraan gender, yakni bahwa laki-laki dan perempuan memiliki kedudukan yang sama di mata agama. Dengan pendekatan ini, teks-teks keagamaan yang cenderung hirarkis ditafsirkan sedemikian rupa sehingga menunjukkan bahwa laki-laki dan perempuan adalah setara.

Secara sosiologis, bergesernya sebuah penafsiran sangat terkait dengan perubahan sosial yang dialami masyarakat, baik secara langsung maupun tidak, tentunya oleh si mufassir sendiri.Tuntutan manusia akan selalu berubah manakala terjadi perubahan sosial. Tuntutan masyarakat tradisional akan berbeda dengan masyarakat modern, begitu seterusnya. Dan perubahan sosial ini akan mempengaruhi cara pandang (paradigma) seseorang dalam melihatrealitas sosial. Perubahan sosial ini menyebabkan terjadinya keteganganketegangan dalam struktur sosial dan memunculkan kesenjangan budaya (cultural lag) yang rnembuat sebuah penafsiran atau asumsi tertentu menjadi “terasing”.Hal ini disebabkan karena penafsiran ataupun asumsi itu tidak lagi mampu menyediakan jawabanjawaban akibat perubahan sosial tersebut. 13

Tafsir feminis merupakan upaya para mufassir-feminis yang menjadikan analisis gender sebagai kerangka kerja penafsiran mereka. Penafsiran ini mendukung kesetaraan

\footnotetext{
${ }^{13}$ Sebagaimana ditulis Johnson, perubahan sosial mengakibatkan orang mempertanyakan ulang penafsiran ataupun asumsi-asumsi lama dan menciptakan asumsi-asumsi ataupun penafsiranpenafsiran yang baru untuk menjawab tuntutan-tuntutan yang baru yang diakibatkan oleh perubahan sosial tersebut.
}

laki-laki dan perempuan. Analisis gender yang digunakannya biasanya secara khusus membahas ayat-ayat yang berkenaan dengan persoalan relasi laki-laki-perempuan.

Seperti hal gerakan feminis, tafsir feminis lahir tidak jauh berbeda karena dipengaruhi oleh hal hal yang bersifat internal dan eksternal. Seperti, jumlah mufasir laki-laki lebih dominan dari pada mufasir perempuan, sehingga kitab tafsir didominasi oleh pemikiran yang berasal dari otak laki-laki hingga masuk pada persoalan perempuan pun cara pandang yang digunakan adalah cara pandang laki-laki. Suara perempuan hampir tidak terwakili atau tidak bisa diwakilkan pada laki-laki. Hal ini mengakibatkan pandangan yang bias tentang hubungan laki-laki dan perempuan. Terdapat kesenjangan antara ajaran normatif-idealis Alquran dengan penafsirannya pada tataran normatif-historis. Ajaran normatif Alquran yang dengan tegas memandang bahwa laki-laki dan perempuan setara di hadapan Allah, karena laki-laki dan perempuan diciptakan untuk saling mengenal, serta kemuliaan manusia tidak dilihat dari jenis kelaminnnya, melainkan dari ketakwaannya kepada Allah Swt (Q.S. alHujurāt [49]:3). Laki-laki dan perempuan sama-sama diibaratkan seperti pakaian. Keduanya harus saling melindungi dan menutupi kekurangannya (Q.S al-Baqarah [2]:187). Laki-laki dan perempuan yang beriman dan memiliki prestasi amal saleh, sama-sama akan mendapat jaminan surga. (Q.S. al-Nisā' [4]:124). Allah Swt juga mengabulkan permohonan untuk menghargai prestasi kerja dan tidak menyia-nyiakan amal perbuatan mereka (Q.S. Äli 'Imrān [3]:195). Bahkan kaum laki-laki dan perempuan samasama disebutkan dan dipuji dengan sifat-sifat yang baik. Mereka dijanjikan memperoleh ampunan dan pahala yang besar (Q.S. alAhzāb [33]: 35).

Memang kadang-kadang Alquran menggunakan bahasa (ungkapan) yang secara literal merujuk pada struktur yang hirarkis, namun secara moral justru ingin menghilangkan subordinasi yang dialami oleh perempuan pada masa-masa sebelum Islam. Jadi sebenarnya, ungkapan Alquran merupakan 
ungkapan yang sarat-akan-pembebasan: termasuk pembebasan perempuan dari dominasi dan eksploitasi kaum laki-laki. ${ }^{14}$

Kenyataan yang ada pada tataran normatifidealis di atas, tidaklah sama dengan kenyataan pada tataran historis-idealis, penafsiran terhadap teks-teks keagamaan dengan nada merendahkan perempuan ini muncul dalam kitab-kitab tafsir . Ayat al-rijāl qawwāmūna 'alā al-nisā' (Q.S. alNisā' [4]:34) misalnya, dipahami oleh para mufassir klasik sebagai penegasan atas keunggulan kaum laki-laki atas kaum perempuan. Bahkan, seluruh ketidakadilan gender bisa dibenarkan dalam Islam menurut pandangan kaum mufassir klasik itu, justru karena adanya ayat ini. ${ }^{15}$

Para mufassir feminis kontemporer, seperti Riffat Hassan, Fatima Mernissi, Amina Wadud, Asghar Ali Engineer — untuk hanya menyebut beberapa tokoh saja-sepakat bahwa penafsiran-penafsiran yang didominasi paradigma ideologi patriarki, memberi kontribusi bagi peminggiran kaum perempuan.Kebanyakan para mufassir klasik adalah kaum laki-laki, sehingga mereka secara 'tidak sadar' kurang mengakomodir kepentingan kaum perempuan.Wajar jika kemudian tafsirtafsir yang diproduksi terasa masih mencerminkan bias-bias patriarki, terlebih ketika dibaca dalam konteks sekarang.

Yang ketiga, menjawab tantangan gagasan HAM, Munculnya penafsiran baru atas ayatayat Alquran tidaklah terlepas dari kesadaran umat manusia dalam masyarakat modern yang dikondisikan oleh konsep Hak Asasi Manusia dan martabat manusia. ${ }^{16}$ Kedua konsep ini, yakni hak asasi dan martabat manusia, memang merupakan wacana ummat Islam kontemporer dalam rangka memenuhi apa yang oleh Bassam Tibi disebut dengan "moralitas internasional", sebuah parameter

\footnotetext{
${ }^{14}$ Asghar Ali Engineer, Islam dan Pembebasan, terj. Hairus Salim (Yogyakarta: LKiS, 1991), 13.

${ }^{15}$ Abū al-Qāsim Jar Allāh al-Zamakhsyarīi, al-Kasysyaf 'an Haqāiq al-Tanzīl wa 'Uyūn al-Aqāwil fì Wujūh al-Ta'wīl (Beirut: Dār al-Fikr, 1977), I: 523-524.

${ }^{16}$ Ashgar Ali Engineer, Hak-hak Perempuan dalam Islam, (Jakarta: LSPPA Yayasan Prakarsa, 1994), 3
}

teoretis yang dikedepankan guna mengatasi konflik antar peradaban Islam dan Barat. ${ }^{17}$ Keempat, Globalisasi yang melanda dunia memaksa umat Islam untuk merumuskan kembali berbagai pemikiran keislaman. Perubahan sosial yang diakibatkan oleh globalisasi menyebabkan pemikiranpemikiran keislaman terdahulu mengalami "keterasingan" karena tidak mampu memberikan jawaban atas berbagai tantangan baru yang muncul akibat perubahan tersebut. Munculnya tantangan-tantangan baru ini mengharuskan dirumuskannya kembali pemikiran-pemikiran Islam agar bisa menjawab tantangan-tantangan tersebut.Masuknya gagasan feminisme di kalangan umat Islam juga jelas tidak bisa dilepaskan dari perkembangan global yang melanda umat Islam.Kelima,

Persentuhan dengan (peradaban) Barat, Jika kecenderungan patriarki muncul, antara lain, karena pemahaman yang tekstualskriptural terhadap teks-teks keagamaan, maka para mufassir-feminis menggunakan instrumen ilmu-ilmu sosial sehingga menghasilkan penafsiran yang sangat berbeda dari yang dikemukakan oleh para mufassir klasik. Jika penafsiran oleh mufassir klasik terhadap teks-teks keagamaan tentang gender menghasilkan gagasan tentang Islampatriarki, maka pada penafsiran oleh mufassir kontemporer menghasilkan gagasan tentang

\footnotetext{
${ }^{17}$ Moralitas internasional merupakan upaya sekularisasi dengan maknanya yang terbatas, yakni pemisahan antara agama sebagai suatu keyakinan etika dengan politik.Ini dilandaskan atas konsensus minimal yang dimiliki peradaban yang berbeda, dalam kaitan ini adalah Islam dan Barat. Tentu saja moralitas internasional bukan didasarkan atas konsep yang sama persis mengenai berbagai hal semisal hak asasi manusia, demokrasi atau yang lain. Masing-masing pihak tetap diberikan untuk bisa berbicara mengenai konsep-konsep internasional tersebut dengan lidah mereka sendiri, yakni dengan

mempraktikkan konsep moralitas internasional yang tidak dipaksakan kepada pihak tertentu. Dalam moralitas internasional keragaman tentu tetap ada. Lihat Bassam Tibi, "Moralitas Internasional sebagai Landasan Lintas Budaya", dalam M. Nasir Tamara dan Elza Pelda Taher (ed.), Agama dan Dialog Antar Peradaban, (Jakarta: Yayasan Paramadina, 1996),
} 
posisi laki-laki dan perempuan yang egaliter dan setara.

\section{Paradigma Tafsir Feminis}

Corak (pendekatan) feminis dalam

menafsirkan Alquran adalah salah satu corak tafsir kontemporer. Tafsir kontemporer adalah tafsir atau penjelasan ayat Alquran yang disesuaikan dengan kondisi kekinian atau saat ini. Pengertian seperti ini sejalan dengan pengertian tajdid yakni usaha untuk menyesuaikan ajaran agama dengan kehidupan kontemporer dengan jalan menakwilkan atau menafsirkan sesuai dengan perkembangan ilmu pengetahuan serta kondisi sosial masyarakat.

Paradigma adalah seperangkat praanggapan konseptual, metafisik dan metodologis dalam tradisi kerja ilmiah. ${ }^{20}$ Setiap produk tafsir pasti memiliki paradigma tertentu, yang membedakan dari produk tafsir lainnya.Oleh karena itu, paradigma tafsir feminis sama dengan paradigm tafsir kontemporer beberapa ulama menyimpulkan bahwa paradigma sebagai berikut :

Pertama, menunjukkan semangat mengembalikan Alquran sebagai kitab petunjuk. Sebelum itu, Alquran bagi mufasir kontemporer diasumsikan sebagai wahyu yang progresif, maka mereka mengembangkan suatu medelpembacaan yang lebih kritis dan produktif. Ali al-Harbi menjelaskan bahwa pembacaan kritis pada

18 Para mufassir feminis sangat menyadari bahwa ilmu sosial yang berasal dari Barat itu sangat penting untuk memahami (mengkritik) gejala (agama) yang ada dalam dunia Islam selama ini. Kecenderungan para mufassir-feminis kepada ilmu-ilmu sosial sendiri tampak bisa dipahami dari latar belakang akademis dan atau aktifitas sosial mereka. Riffat Hassan misalnya, dengan terang-terangan mengakui perlunya mengembangkan apa yang oleh Barat disebut dengan "teologi feminis" untuk membebaskan umat Islam dari struktur yang tidak adil dan tidak memungkinkan terjadinya hubungan yang hidup antara laki-laki dan perempuan.Fattima Mensissi dan Riffat Hassan, Setara di Hadapan Allah, (Jakarta: LSPPA Yayasan Prakarsa, 2000), 40.

19 M. Quraisy Shihab, Membumikan Al-Alquran, (Bandung: Mizan, 1998), 93.

${ }^{20}$ Lihat Ian Barbour, Juru Bicara Tuhan: Antara Sains dan Agama, terj. E.R. Muhammad (Bandung: Mizan, 2003), 81.
Alquran adalah pembacaan atas teks Alquran yang tidak terbaca, dan ingin ${ }_{21}$ menyingkap kembali apa yang tak terbaca itu.

Selain itu mufasir kontemporer, juga menyakini bahwa Alquran tidaklah turun pada masyarakat hampa budaya, ia lahir dalam struktur bangsa Arab abad ke tujuh. Ia juga ditulis dengan berpijak pada aturan-aturan budaya bangsa Arab selama dua puluh tahun. Maka petunjuk-petunjuk Alquran yang bersifat universal juga dapat dirumuskan dengan mepertimbangkan situsi-historis masa itu, untuk kemudian dirumuskan kembali sesuai dengan konteks kekinian.

Kedua, berbeda dengan tafsir klasik yang berkonsentrasi pada kajian makna kata dari segi i'rāb dan penjelasan segi teknis kebahasan yang di kandung oleh redaksi ayat, maka paradigma tafsir kontemporer lebih menitik beratkan pada kajian epistemologismetodologis. Penitik-beratan aspek tersebut melahirkan pandangan yang mencoba mencari ada apa di balik teks Alquran, karena yang dinginkan mereka hasil pembacaan yang produktif terhadapAlquran bukan pembacaan yang repetitif. Mereka tidak berhenti pada pemaknaan literal dari ayat-ayat Alquran, karena yang mereka cari adalah maksud dan tujuan dari makna-makna literal itu ayat-ayat tersebut.

Ketiga, berbeda dengan tafsir klasik yang menggunakan praktek penafsir yang linieratomistik seperti diurai di atas, tafsir kontemporer memiliki paradigma yang bernuansa hermeneutik. Menurut, Roger Trigg hermenutika merupakan suatu model penafsiran terhadap teks tradisional (klasik), dimana suatu permasalahan harus selalu diarahkan agar teks selalu dapat dipahami dalam konteks kekinian yang situasinnya berbeda. $^{22}$ Nuansa hermeunitika yang menonjol pada tafsir kontemporer, membuat mereka selalu curiga pada adanya kepentingan ideologis di balik pada teks tersebut. Poin ini yang membuat tafsir kontemporer selamat

\footnotetext{
${ }^{21}$ Āli al-Harbī, Naqd al-Nash, (Beirut: al-Markaz al-Tsaqāfi, 1995),204-205.

${ }^{22}$ Dikutip dari Komarudin Hidayat, 62.
} 
dari sektarianisme,seperti yang pernah dialami oleh mayoritas tafsir klasik.

Keempat, paradigma tafsir yang terahir ini adalah konsekuensi logis dari tiga paradigma di atas, karena tafsir kontemporer itu didasarkan pada semangat membuktikan Alquran sebagai hidayah, rahmat untuk semua penghuni alam, menggunakan hermeneutika, sehingga terbebas dari pandangan sektarianisme, maka paradigma tafsir kontemporer itu kritis dan ilmiah.

Menurut Mustaqim, keilmiahan bisa dilihat dari produk tafsir kontemporer yang dapat diuji kebenarannya berdasarkan konsistensi metodologi yang dipakai dan siap menerima kritik dari komunitas akademik. Selain itu, tafsir kontemporer disebut kritis karena umumnya mufasir kontemporer tidak terjebak pada fanatisme madzhab, mereka justru kritis terhadap beberapa pandanganklasik atau kontemporer yang dianggaptidak kompatibel dengan konteks kekiniaan.

Sebagaimana telah disinggung diatas, bahwa Tafsir feminis lahir dengan berbagai dorongan dari sisi internal maupun eksternal, tafsir feminis kemudian memilih perspektif keadilan yang menjadi pertimbangan para mufassir-feminis kontemporer dalam memahami ayat-ayat Alquran tentang gender, demi terciptanya relasi yang adil bagi perempuan dan laki-laki.

Karena interaksi terhadap produk paradigma tafsir Alquran yang bias gender akan menjadi mode of conduct (pola perilaku) tertentu, maka merubah paradigma menafsir menjadi sebuah keniscayaan. Disebabkan ada hubungan positif antara pola pikir (mode of thought) masyarakat yang terbentuk melalui teks-teks agama dengan pola perilaku mereka (mode of conduct) Terhadap teks-teks keagamaan, seperti tafsir, fikih, tasawuf dan sebagainya yang dikonsumsi masyarakat jelas ikut mempengaruhi pola perilaku masyarakat. Artinya, jika paradigma tafsir yang dikonsumsi tersebut bersifat deskriminatif terhadap perempuan, maka biasanya perilaku masyarakat juga cenderung akan diskriminatif.
Untuk itu, diperlukan semacam "rekonstruksi" dan pergeseran paradigma (taghayyur manhāj al-fikr) terhadap model tafsir patriarkis yang cenderung meminggirkan peranan kaum perempuan.Sebab ternyata pergeseran paradigma tafsir memiliki implikasi dalam merekonstruksi sosial, tak terkecuali dalam masalah-masalah perempuan.

Paradigma tafsir feminis adalah sebuah genre tersendiri yang muncul di era kontemporer, yang isu gender menjadi isu global. Paradigma ini berangkat dari asumsi, bahwa prinsip dasar Alquran dalam relasi laki-laki dan perempuan adalah keadilan (al-'adālah), kesetaraan (almusāwah), al-ma'rūf

(kepantasan), syurā (musyawarah). Maka produk-produk penafsiran klasik yang bertentangan dengan prinsip-prinsip tersebut akan dinilai tidak tepat, terutama ketika diterapkan untuk konteks kekininian, sebab situasi dan kondisinya jelas berbeda sama sekali dengan zaman dulu.

Model analisis paradigma tafsir feminis ialah analisis gen-der, yang secara tegas membedakan antara kodrat sebagai sesuatu yang tidak bisa berubah, dengan gender sebagai konstruksi sosial yang bisa berubah. Maka tidak salah, jika kemudian pendekatan hermeneutik dengan metode tafsir tematik menjadi pilihan dalam mengkaji ayat-ayat tentang relasi gender. Sebab dengan metodologi seperti itu, diharapkan produk tafsir akan lebih intersubyektif dan kritis melihat problem relasi gender.

Pendekatan feminisme yang kemudian dijadikan dalam memahami ayat-yat Alquran yang terlanjur ditafsirkan secara patriarkal, mereka memulai dari apa yang oleh para feminis disebut "ketidakadilan gender", dan terlanjur dijustifikasi agama ini. Dikarenakan hal tersebut merupakan pangkal penindasan terhadap kaum perempuan oleh laki-laki. Nampak terlihat dari Citra Tuhan yang lakilaki, diakui atau tidak, itulah yang paling jelas sekaligus paling tak kentara pengaruhnya dalam pemahaman keagamaan. ${ }^{24}$

\footnotetext{
Abdul Mustaqim, Epistemologi Tafsir

Kontemporer, (Yogyakarta: LKiS,2012), 65.
} 
Adanya teks-teks suci keagamaan (dalam konteks ini adalah Alquran dan Hadis) yang secara harfiah memosisikan laki-laki sebagai pihak superior - yang kemudian ditafsirkan secara literalistik-skripturalistik oleh para mufassir klasik-semakin memperkukuh pandangan tentang superioritas laki-laki atas perempuan ini.

Maka dari itu, penafsiran mengenai ayatayat relasi gender yang tekstual dan bias gender perlu dirubah lebih kontekstual dan sejalan terhadap nilai-nilai ideal moral Alquran yang sangat berpihak kepada nilainilai keadilan, egaliter dan kemanusiaan. Contoh yang populer berkaitan dengan ayatayat relasi gender adalah ayat tentang kepemimpinan perempuan, pembagian warisan laki-laki dan perempuan, masalah persaksian, poligami dan sebagainya. Penafsiran atas ayat-ayat tersebut bisa dikontekstualisikan sesuai dengan nilai-nilai etik Alqurani.

\section{Standar Validitas Tafsir Feminis}

Salah satu problem epistemologi dalam penafsiran Alquran adalah hal yang berkenaan dengan standar kebenaran sebuah penafsiran. Karena produk penafsiran Alquran biasanya menjadi ajaran dan pegangan dalam hidup manusia.

Membuat standarisasi kebenaran bagi penafsiran dengan menggunakan kacamata feminisme memang hal subjektif. Subjektif bukan berarti tidak baik apalagi salah, subyektif yang penulis maksud adalah sebuah tawaran yang tentu tidak bergaransi benar namun bukan berarti tidak ada kebenaran sama sekali.

Seperti disinggung di muka, bahwa paradigma tafsir feminis ini berangkat dari suatu asumsi dasar bahwa Alquran itu mendudukkan laki-laki dan perempuan setara di hadapan Allah, yang membedakan keduanya hanyalah ketakwaannya. Sedangkan pendekatan yang dipakai adalah pendekatan analisis gender, yaitu dengan melakukan diferensiasi secara tegas antara kodrat sebagai

\footnotetext{
${ }^{24}$ Carol P Christ dan Judith Plascow (ed.), Woman Spirit Rising: a Feminist Reader in Religion (San Fransisco: Harper \& Row Publishing, 1979), 4.
}

sesuatu yang given from God dan tak dapat dirubah (unchangeable), dengan gender sebagai sebuah konstruk sosial yang bisa dirubah (changeable).

Maka validitas tafsir dengan pendekatan feminis meniscayakan standar koherensi dalam penafsirannya. Standar koherensi yang dimaksud oleh penulis, bahwa kebenaran itu tidak dibentuk oleh hubungan pendapat dengan sesuatu yang lain, tapi dibentuk oleh keyakinan-keyakinan itu sendiri. Dengan kata lain, jika tafsir feminis meyakini bahwa tafsir klasik, dan Bahasa Arab turut menyumbangkan atau bahkan menguatkan pandangan yang patriarkal, lalu mufassir feminis berusaha membenahi dengan cara membuat diferensiasi (hubunngan perempuan dan laki-laki) mana yang dapat diubah dan tidak diubah. Sepanjang mufasir feminis itu konsisten dalam tataran logis dan filosofis pada paparannya maka tafsir itu memiliki salah satu standar kebenaran tafsir.

Paradigma tafsir feminis ini tentu akan 'bertabrakan' dengan paradigma lama terhadap penafsiran klasik yang selama ini menganggap bahwa ayat-ayat yang berkaitan dengan relasi gender sebagai ayat-ayat qath'iyyu al-dalālah (ayat yang sudah mapan dan pasti penafsirannya). Hal ini berbeda dengan para mufassir feminis ayat-ayat relasi gender ebi merupakan ayat yang bersifat sosiologis yang penafsirannya bisa kontekstual sesuai dengan perubahan sosial masyarakat.

Oleh karena itu, jika mufassir feminis, menganggap bahwa ayat-ayat relasi gender lebih merupakan ayat-ayat yang bersifat sosiologis yang penafsirannya bisa kontekstual sesuai dengan perubahan sosial masyarakat. Sepanjang argumenatasi mufassir feminis itu berdasarkan data dan fakta yang sesuai dengan apa yang diungkapan, atau terdapat kesesuain anatara pernyataan suatu fakta (keputusan) dengan situasi lingkungan yang diinterpretasikannya, singkatnya tafsir 
feminis itu memenuhi standar korespondensi. Maka, tafsir itu memiliki kemungkinan benar

Mufassir feminis sangat konsisten dalam mengubah orientasi penafsiran ayat-ayat relasi gender yang sangat tekstual, dan bias gender menjadi lebih kontekstual dan sejalan dengan nilai-nilai ideal moral Alquran, yang sangat berpihak kepada nilai-nilai keadilan, egaliter dan kemanusiaan. Semangat ini semata bertujuan menyelaraskan antar ajaran normatif-Idealias Alquran dengan tafsir Alquran yang bersifat historis-idealis. Sehingga ia bisa bersambut tangan dengan segala macam tuntutan zaman, seperti HAM, arus globalisasi, tuntutan perkembangan ilmu pengetahuan dan teknologi. Maka, jika tafsir feminis itu dapat memenuhi semuanya, artinya ia dapat memenuhi standar pragmatisme. Karena salah satu tolak ukur pragmatisme itu adalah manakala sebuah penafsiran itu secara empiris mampu memberikan solusi bagi penyelesain problem kemanusiaan yang ada.

\section{SIMPULAN}

Poin penting yang dapat diambil dari pemikiran para feminis ini adalah adanya upaya untuk membongkar pemikiran lama dan mitos-mitos lama yang disebabkan oleh penafsiran bias-bias patriarki.Upaya itu dimulai dengan melakukan rekonstruksi metodologi tafsirnya yang diharapkan berimplikasi bagi rekonstruksi teologi dan sosial. Ini mengingat bahwa adanya mitosmitos dan penafsiran yang bias patriarki dapat menyebabkan ketidakadilan gender dalam kehidupan masyarakat, yang sebenarnya tidak beriringan dengan spirit dan prinsip dasar dan Alquran.

\section{DAFTAR PUSTAKA}

Abu Zaid, Nashr Hamid. Women in the Discourse of Crisis, The Legal Research and Resource center for Human Right pages. (LRRC). Cairo, Egypt.

Barbour, Ian. Juru Bicara Tuhan; Antara Sains dan Agama, terj. E.R. Muhammad. Bandung: Mizan, 2003.

Carol P. Christ dan Judith Plascow (eds.), Woman Spirit Rising: a Feminist Reader in
Religion, San Fransisco: Harper \& Row Publishing, 1979.

Engineer, Asghar Ali. Islam dan Pembebasan, terj. Hairus Salim. Yogyakarta: LkiS, 1991.

Hakim, M. Arif, "Gerakan Perempuan dalam Perspektif Ideologis", dalam Media Indonesia, 14 Agustus, 1993.

Harb, Ali. Naqd al-Nash. Beirut, al-Markaz al-Tsaqofi, 1995.

Himawan, Anang Haris. "Teologi Feminisme dalam Budaya Global: Telaah Ktitis Fiqh Perempuan", dalam Jurnal Ulumul Qur'an, No: 4 Vol VII, (1997), 35-42.

John M. Echol dan Hassan Shadily. Kampus Inggris-Indonesia, cet. xix, Jakarta: Gramedia, 1993.

Kamla Bashin dan Nighat Said Khan. Persoalan Pokok Mengenai Feminisme dan Relevansinya, terj, S. Harlina Jakarta: Gramedia, 1995.

Markus, Lis. "Feminisme dalam Wacana dan Gerakan Perempuan Era Postmodernisme”, Makalah, disampaikan dalam halaqoh ulama perempuan LSM Rahima, Depok, 5 Januari, 2010.

Megawangi, Ratna. "Feminisme: Menindas Peran Ibu Rumah Tangga", dalam Ulumul Qur'an, edisi khusus No: 5 \& 6 Vol V, 1994, p. 30-41.

Mustaqim, Abdul. Epistemologi tafsir Kontemporer, LkiS, 2012.

Muhammad bin Iyas. Badaiz Zuhur fi Waqaid Duhur, Beirut: Maktabah Saqafiyyah, tt.

Shihab, M. Quraisy. Membumikan AlQur'an,Bandung: Mizan, 1998.

Suryakusuma "Specific Methodological Problem in Feminism Research", dalam

State Ibuism: The Social Construction of Womenhood in Indonesia, New Order, Tesis di Den Haag, 1987.

Thabari, Ibn Jarir. Jami' al-Bayan fi Tafsiri alQur'an,. Kairo: 1057-1969.

Turtle, Lisa. Encyclopedia of Feminisme. New York: Facts of File Publication, 1986. Zamakhsyari, Abu al-Qasim Jar Allah. alKasysyaf 'an Haqaiq al-Tanzil wa 'Uyun al-Aqawil fi Wujuh al-Ta'wil, Beirut: Dar al-Fikr, 1977. 